\title{
Satisfaction level of participants in workers social security agency (BPJS) employment services in health care in Indonesia
}

\section{Siagian}

Original Articles

Faculty of Social and Political Sciences, University of Sumatera Utara, Indonesia

\section{Correspondence to:}

Lecturer of Department of Social Welfare, Head of the Laboratory of Social Welfare Faculty,

School of Social and Political Science, Universitas Sumatera Utara,

Jl. Dr. A. Sofian No. 1 Telp/Fax: 061-8221346 - Medan-Indonesia Postal Code 20122;

e-mail: matias.siagian@ymail.com

Submitted: 24.7.2016

Revised: 7.8 .2016

Accepted: 17.8.2016

\section{Reviewers:}

A. Shahum

University of North Carolina at Chapel Hill School of Medicine, USA

P. Kalanin

Pavol Jozef Šafárik University in Košice, Slovak Republic

\section{Keywords:}

Health care, BPJS Employment program, welfare, satisfaction levels.

CSWHI 2016; 7(2): 97-104 @ 2016 Clinical Social Work and Health Intervention

\section{Abstract:}

This study aims to determine the level of satisfaction of health services by participants of BPJS Employment and families living in the village of Tanjung Gusta, to the area of Medan. The study sample consisted of 41 participants working families of BPJS Employment determined using purposive sampling technique, with the use of a minimum of three times the health care facility as a condition. Data were collected using a questionnaire and analyzed using descriptive statistics. To determine the level of employee satisfaction, the measurement of data was using Likert scale.

The study concluded, in general, Social Security service has not been satisfactory. Neither the implementation of stages of socialization and registration, turns out to be not satisfactory, in the sense that it is still in the stage of neutral or unsatisfactory. While special in the implementation of health services it turns out that it is not satisfying workers and families. 


\section{Introduction}

One of the changes in the employment policies in Indonesia is the abolition of Social Security Workers and replaced with a new policy, namely Workers Social Security Agency (BPJS) is a public program that provides protection for workers in order to address specific socio-economic risks and the implementation of its mechanisms of social insurance. In accordance with Law No. 24 of 2011 on BPJS, PT. Jamsostek transformed into Workers Social Security Agency (BPJS) since January 1, 2014. The amendment became effective since July 1 , 2015. Workers have a strategic position, because it is an executor of plans established by managerial. Therefore, it is reasonable to keep an eye on the welfare of employees and their families so that they can optimally contribute their labor in the production process (Simanjuntak, 2005).

Attention to workers are still lacking, whereas their participation in development is strategic. As a result of these conditions, the level of welfare of workers or employees is still relatively low. Including workers' health problems. Health development is an integral part of the development of social welfare (Sinaga, 2005). As the decisive factor in winning the competition, the protection of labor is very important so that the workers can contribute its expertise in the production process through the operationalization of science and technology (Mahyuni, 2006). Labour, as well as other poor people in general do not have access to education and health services through market mechanisms. In these circumstances, the creation of a special mechanism in the form of social security is a creative activity that must be done to meet the needs of the workers (Gofin, Gofin, Neumark 2002).

Zastro (2005) suggests, at least four attempts or services performed in the realization of social welfare, ie: 1)Personal services (such as individual counseling, group counseling, rehabilitation, and social therapy), 2)Protection services (such as consumer protection, legal remedies in order to truly protect the public, housing and health care services), 3)Information services (such as consultancy, information for consumers, education, library services, financial consulting), and 4) Care services (such as child care, care of workers, public welfare programs and social security programs). The state develops a social security system for all citizens and empower the weak and underprivileged in accordance with human dignity (Pakpahan and Sihombing 2012).

If we trace back, then we know that the formation history of BPJS Employment was previously called Jamsostek experienced a long process, starting from Law No.33/1947 jo Law No.2 / 1951 on the work accidents, Ministry of Labour (PMP) 48/1952 jo PMP No.8 / 1956 on setting up of aids for attempts in the implementation of health workers, PMP No.15 / 1957 on the establishment of the Foundation of Social Workers, PMP No.5 / 1964 on the establishment of Social Security of Fund Foundation (YDJS), the enactment of Law No.14 / 1969 on the Principles of Labor. Chronologically the process of the birth of workers' social insurance has become more transparent.

After experiencing progress and development, both related to the legal basis, forms of protection as well as for the organization, in 1977 obtained an important milestone with the issuance of Government Regulation (PP) 331977 on the implementation of workers' social insurance programs (ASTEK), that obliges each employer / private entrepreneurs and state enterprises to follow ASTEK program. It was also published PP No.34 / 1977 on the establishment of the organizer container of ASTEK namely Perum Astek.

Progress of Companies that promote the interests and basic rights of Manpower in 
Indonesia continues. Until now, PT. Jamsostek (Persero) provides protection of 4 (four) programs, that includes Accident Insurance Program (JKK), Death Benefit (JKM), Old Age Security (JHT) and Health Insurance (JPK) for all workers and their families. In 2011, enacted Law No. 24 of 2011 on Social Security Agency. In accordance with the mandate of the law, dated 1 Janury 2014 PT Jamsostek will turn into Public Law Firm. PT Jamsostek still believed to hold workers' social security programs, which include JKK, JKM, JHT with the addition of pensions started July 1, 2015 (Lagunturu, 2014). Companies that are directly concerned with the welfare of workers and their families. Therefore, the company is obliged to make prosper workers and their families. One way to ease the burden on employers in implementing its obligations, among others, to provide accident benefits, health care and guarantees in old age for workers are with the policy of entrepreneurs participate their works in Jamsostek (Lubis, 2007).

A quiet interesting question rose, whether by the enactment of a new regulation in the area of employment the workers would feel the benefits? We try to do a study of the previous policy, where the Workers' Social Security policies still apply. Head of Regional Office I PT. Jamsostek (Persero) H. Mas'ud Muhammad argued that the company's participation in the implementation of the Social Security program for its employees in the Territory of NAD, North Sumatra and West Sumatra, which is the working area is still very alarming. It is evident from the number of workers that reached to 9.3 million, while the number of participants of Health Insurance (JPK) includes single participants of 4,951 people, married 88.725 people, 218.489 families and the insured (the entirely registered in JPK) as many as 356.725 people (Pelita Online Daily, 2009).

A significant difference between the number of companies and workers with participants in Jamsosstek sets up a kind of alternative institutions, organizers of Jamsostek, among others, General Services Agency by the Provincial Government of South Sumatra. This breakthrough is based on the idea of the responsibility of Local Government on community welfare in accordance with the demands of regional autonomy as stipulated in Law No. 32 Year 2004 on Regional Government. However, the welfare of society is a central issue in governance, both by the Central Government and Local Government (Retnaningsih, Misnaniarti, Aini 2012).

The implementation of Jamsostek classified as bad is rooted in monopolistic practices. Jamsostek implemented in accordance with the legislation in force. Currently the rule in question is Act No. 3 of 1992 on Social Security of Labor. Article 4 Paragraph (3) of the Act regulating the requirements and procedures for the implementation of the Social Security program, which is implemented by Government Regulation No. 14 of 1993 and Government Regulation No. 36 of 1995 by establishing PT. Jamsostek (Persero) as a single entity organizer of Social Security. These conditions require legal reforms in the framework of the implementation of Jamsostek (Wijayanti, 2007).

Public services in the form of social security is a form of government protection for workers, whose implementation is motivated by various factors, such as (1) the increasing role of labor both in quantity and quality, (2) the increasing use of technology in various sectors of business activity, and (3) the higher the risk threatens the safety, health and welfare of the workforce (Basjir, 2003). The importance of a good implementation of social security for workers in Indonesia is increasingly urgent considering the majority of workers in Indonesia in the private sector are those with little education (junior and equal $66.75 \%$ ). But until now 
the state has not been able to develop social security programs as appropriate (Suparjan, 2010).

It should be recognized that the implementation of the health insurance program of poor families are still struggling with various problems. Data is inaccurate, socialization is not optimal, full service is not free, extortion, denial, bad service, stand in long lines, cramped space, action is not immediate, late physician and hospital refuse are a basket of issues that deprive the poor (Kodim, 2009). Furthermore it can be argued that the health service satisfaction is the result of the influence of skills, knowledge, attitudes, behavior and the provision of facilities. Patients and families in expressing satisfaction or dissatisfaction with health care depends on the experience before and after receiving medical care in a hospital (Widujani, Mukti, Hendrartini 2004).

Low levels of satisfaction on public services is a common symptom. The results about the comparison of participant satisfaction level of mandatory and voluntary health insurance for the quality of health services in the city of Kendari level I shows: (1) 34.26\% doctor service for users of compulsory health insurance, voluntary health insurance users is $31.00 \%$, (2) Prescribing drug $21.67 \%$ for compulsory health insurance, voluntary health insurance users $18.76 \%$, (3) $7.51 \%$ referral system for compulsory health insurance users, while for the voluntary health insurance $6.46 \%$,
(4) access of services $21,46 \%$ for the compulsory health insurance, voluntary health insurance user $19.40 \%$ (5) $24.18 \%$ of the physical environment facilities for users of compulsory health insurance, voluntary health insurance user 21.81\% (Aga, Hendrartini, Margo 2005).

\section{Research Method}

The research conducted is a descriptive study, using a quantitative approach. The research objective is specifically to obtain a picture of the level of satisfaction of workers and their families in the service of BPJS Employment. The study was conducted in the village of Tanjung Gusta Subdistrict of Sunggal District of Deli Serdang, North Sumatra. Mulyo Rejo village is located on the outskirts of the city of Medan. The study population was family of labor of BPJS Employment participants numbered 196 families. The sampling technique was done by using purposive technique by defining conditions, namely families who have used at least 3 times the facility of BPJS Employment in health care (Siagian, 2012).

\section{Results}

\section{Socialization of BPJS Employment Program}

The level of employee satisfaction with regard to the implementation of this socialization is:

Table 1 The level of employee satisfaction in Socialization of BPJS Employment Program

\begin{tabular}{|c|l|c|c|c|c|}
\hline No. & \multicolumn{1}{|c|}{ Socialization Activity } & Satisfied & Neutral & $\begin{array}{c}\text { Not } \\
\text { Satisfied }\end{array}$ & Total \\
\hline 1 & Timing of information & 12 & 17 & 12 & 41 \\
\hline 2 & How information is provided & 14 & 21 & 6 & 41 \\
\hline 3 & completeness of information & 11 & 18 & 12 & 41 \\
\hline
\end{tabular}




\begin{tabular}{|c|l|c|c|c|c|}
\hline 4 & $\begin{array}{l}\text { Space availability for announcements } \\
\text { and completeness of information }\end{array}$ & 12 & 21 & 8 & 41 \\
\hline 5 & Understanding information & 11 & 16 & 14 & 41 \\
\hline $\begin{array}{c}\text { Amount of } \\
\text { Each Category } \\
\text { of Answers }\end{array}$ & & 60 & 93 & 52 & 205 \\
\hline
\end{tabular}

Source: research results, 2015.

There is a company providing information included as complete, less complete or not complete. This condition gives birth to an impression in a form of working satisfactory level related to the socialization of BPJS Employment. Likert scale calculations produce an average of 0,039 . This suggests that workers in category "neutral", in the sense of excluding "satisfied" and also includes "not satisfied" in the process of socialization of BPJS Employment.

\section{Process of Registration}

The following are the data related to the level of worker satisfaction related to participant registration process.

Becomes participants in BPJS Employment program is workers' rights. In connection to rights the company's involvement in the process of registration of workers as a participant of BPJS Employment is different. This certainly gives a distinct impression in the form of employee satisfaction levels in the process of enrollment into the program participants of BPJS Employment. The results of likert scale calculation produces a mean of 0.284 , which means that employees in the category of "neutral" in the implementation of the registration of a participant of Jamsostek.

\section{Implementation of Health Care}

In Table 3 below are presented overview of the level of satisfaction in health care worker.

This service conditions give effect to the level of satisfaction in health care workers. Another factor is the attitude of officers. These factors are certainly affecting feelings of patients and their families. The attitude is

Table 2 The level of employee satisfaction in the Registration as BPJS Employment Program Participant

\begin{tabular}{|c|l|c|c|c|c|}
\hline No. & \multicolumn{1}{|c|}{ Registration Actvity } & Satisfied & $\begin{array}{c}\text { Less } \\
\text { Satisfied }\end{array}$ & $\begin{array}{c}\text { Not } \\
\text { Satisfied }\end{array}$ & Total \\
\hline 1 & $\begin{array}{l}\text { The involvement of companies in } \\
\text { registration }\end{array}$ & 21 & 12 & 8 & 41 \\
\hline 2 & Registration procedure & 20 & 14 & 7 & 41 \\
\hline 3 & Duration to become participants & 17 & 16 & 8 & 41 \\
\hline \multicolumn{2}{|l|}{ Amount of Each Category of Answers } & 58 & 42 & 23 & 123 \\
\hline
\end{tabular}

Source: research results, 2015. 
Table 3 Levels of Satisfactory in Heath Care

\begin{tabular}{|c|l|c|c|c|c|}
\hline No. & \multicolumn{1}{|c|}{ Service Activity of JPK } & Satisfied & Less Satisfied & Not Satisfied & Total \\
\hline 1 & Engagement / corporate concern & 21 & 14 & 6 & 41 \\
\hline 2 & Administrative procedures & 15 & 15 & 11 & 41 \\
\hline 3 & Administrative services & 11 & 15 & 15 & 41 \\
\hline 4 & Speed of service & 8 & 12 & 21 & 41 \\
\hline 5 & Attitude of officers & 8 & 14 & 19 & 41 \\
\hline 6 & Completeness of drugs & 12 & 16 & 13 & 41 \\
\hline 7 & Quality of drugs & 12 & 15 & 14 & 41 \\
\hline 8 & Quality of medical services & 11 & 17 & 13 & 41 \\
\hline \multicolumn{2}{|l|}{ Amount of Each Category of Answers } & 98 & 118 & 112 & 328 \\
\hline
\end{tabular}

Source: research results, 2015.

a picture of appreciation, hospital officials and business partners of BPJS Employment program to the patient, which in turn affects the level of employee satisfaction in the implementation of health. The result of likert scale calculation generates a mean amounted to -0.004 , which means that employees in the category of "not satisfied" in health care.

\section{Discussion}

The results showed that the implementation of the BPJS Employment program which is a constitutional mandate (Pakpahan, Sihombing, 2012) turns out is still not satisfying workers and families participating in the program. Admittedly, working class communities and other poor communities are often marginalized in various public services. As if the competent authorities forget that workers are the key holder, in the sense of having a great contribution and strategic in the production process ( $\mathrm{Si}$ manjuntak, 2005), thus fulfillment of various types of their needs are necessary, including various service items included in the program of BPJS employment should be taken into great account and need attention sincerely (Sinaga, 2005), which among others realized through the implementation of the quality BPJS Employment and satisfying workers. With the BPJS Employment program, workers will feel comfortable in working, so that it can contribute its expertise to the fullest in the production process through the operationalization of science and technology, (Mahyuni Eka Lestari 2006).

Accordingly, state initiative in establishing Social Security as labor rights is a public policy that benefits companies (Manullang, Sendjun, 2005). Furthermore, the social security system was first put forward Otto von Bismark (Sulastomo, 2008) was a statewide initiative in order to create conducive conditions in the production process by reducing the burden on companies to implement their obligation (Lopez, 2007). However the company's management was less aware of the positive side of such a large program of implementation of BPJS Employment) against the company. It is known by the socialization of Social Security program that is not good, in the sense of not satisfying the employees (according to the size of the 
Likert scale is only in the category of "neutral", with a mean of 0.039). If the company does not have the qualified human resources in the dissemination, management of companies may work together to implement socialization of BPJS Employment program (Wahab, 2002). With this level of education the majority of the workforce in Indonesia is still low (Suparjan 2010) certainly needed a simple bureaucratic procedures making it easier for employees to fill out the form and register at the nearest office of BPJS.

Zastro argued, health care is part of the four attempts or services performed in the realization of social welfare (Zastrow, 2008). Health care is an absolute necessity for workers around the world, because they, like other poor people do not have access if the health service can only be met through market mechanisms. Therefore, the health service through BPJS Employment program is a creative effort in order to meet the needs of labor (Gofin, Neumark, 2002). Unfortunately, the service which is so important is just not going well, which according to the size of the Likert scale results showed that employee is in the category of "not satisfied", with a mean of $-0,004$. The results of this study are identical to the results of research on comparison of the level of participant satisfaction mandatory and voluntary health insurance for the quality of health services in the city of Kendari level I, where the bad condition occurs in all service elements (Aga, Hendrartini, Margo, 2005). This indicates the need for the empowerment of the ranks of health workers, both in terms of skills, knowledge, behaviors and attitudes (Widujani, Mukti, Hendrartini, 2004).

\section{Conclusion}

The results of the analysis of the data on satisfaction levels of workers and their families who participated in BPJS Employment program in Tanjung Gusta concluded, of the three that were studied and analyzed, elements of socialization and registration as the first and second stages in the implementation of BPJS Employment program showed workers and families have not been satisfied, but only in neutral level. If we examine specifically the elements that contribute negatively to the level of satisfaction in the implementation of BPJS Employment BPJS program, it can be seen that the contributors mainly from BPJS partners, such as hospitals and clinics. Weak points are mainly on administrative services, speed of service, the attitude of the officers, the completeness of drugs, drug quality and the quality of medical services. Elements of this activity is substantial.

\section{Suggestion}

Companies should be more proactive in empowering BPJS Employment program implementation, among others, by socializing early on to employees since someone was hired and have started working in the company. The human resources department in any company should be trained specifically in order to truly understand the Social Security program and is able to provide comprehensive information to employees so that they really understand it.

\section{References}

1. AGA, N. A., HENDRARTINI J., MARGO V. 2012. Comparison of Participants Satisfaction Rate Mandatory and Voluntary Health Insurance on Quality of Health Care Level I. Journal of Health Services Management. 8(4), pp. 186-201.

2. BASJIR, W. 2003. Informalization, Social Security and Labor Organizing. Journal of Social Analysis. 8(8). pp. 44-56.

3. GOFIN, J., GOFIN, R., NEUMARK Y. 2002. The Jerusalem Experience: Three 
Decades of Service, Research, and Traning in Community Primary Care. American Journal of Public Health. 92, (11). Pp.89109.

4. Pelita Online Daily, Wednesday, January 27, 2009, accessed from http://www.hupelita. com/baca.php?id= 63654, June 30, 2010, at $14: 38 \mathrm{pm}$.

5. KODIM, N. 2009. Social Security Service Should Honor, Not niceties, Medical Journal of Indonesia. 35(1), pp.23-45,.

6. LAGUNTURU, 2013. History Assessing Health Care in Indonesia, Waspada Publisher.

7. LUBIS, D. 2014. Implementation of Health Insurance by PT. Health Insurance and PT. Social Security. Insight Journal. 13(02). pp. 154-164.

8. MAHYUNI, E. L. 2006. Application Evaluation Work Attitude 5-S in Improving Corporate Productivity in PT. ABC, 2005. Info Public Health, The Journal of Public Health. X(1), pp. 74-75..

9. MANULlANG, S. 2005. Principal Employment Law Indonesia. PT. Rineke Copyright: Jakarta.

10. PAKPAHAN, R., SIHOMBING, E. 2012. Responsibility of States in the Implementation of Social Security. Journals Legislation Indonesia. 9(2). pp. 169-182.

11. RETNANINGSIH E., MISNANIARTI, AINI, A. 2012. Eligibility Assessment Agency Public Service and Social Security Implementation of Alternative Forms of South Sumatra Universe accordance with the Regulation of the National Social Security System. Journal of Health Services Management. 15(01). pp. 20-21.
12. SIAGIAN, M. 2010. Social Research Methods Practical Guidelines Research Division of Social Sciences and Health. Grasindo Monoratama: Medan.

13. SIMANJUNTAK, P. 2005. New Law on Trade Union / Labour Union. International Labour Office: Jakarta.

14. SINAGA, M. 2005. Health On The saleswoman. Info Public Health, The Journal of Public Health. 9(1). pp. 33-54.

15. SULASTOMO 2008. National Social Security System Introductions. Rajawali Press. Jakarta.

16. SUPARJAN 2010. Community-Based Social Security: Response Failure of the State in the Provision of Welfare Assurance. Journal of Social and Political Sciences. 13(3), pp. 2-3.

17. WAHAB, Z. 2002. Pensions and Social Security Workers in Indonesia. PT. Citra Aditya Bakti; Bandung.

18. WIDUJANI I., MUKTI, A., HENDRARTINI 2004. Fees Fee Amount relations with Askes in RSU Participant Satisfaction Wangaya. Journal of Health Services Management. 7(3), p. 142-158.

19. WIJAYANTI, A. 2007. Legal Reform in the Implementation of Social Security For private sector employees. Electronic Journal UM Surabaya. 1(1), pp. 2-12.

20. ZASTROW, C. 2008. Introduction to Social Work and Social Welfare. Thomson Brokks: Belmont, USA. 